\title{
Blue fan palm distribution and seed removal patterns in three desert oases of northern Baja California, Mexico
}

\author{
Elisabet V. Wehncke • Xavier López-Medellín • \\ Exequiel Ezcurra
}

Received: 26 October 2008/Accepted: 20 October 2009/Published online: 11 November 2009

(C) The Author(s) 2009. This article is published with open access at Springerlink.com

\begin{abstract}
Information on the current processes controlling the distribution patterns of relict palm populations at the limit of their northwestern distribution in America are poorly known. We explored the importance of post-dispersal seed removal by vertebrates, recruitment, and distribution patterns of the blue fan palm, Brahea armata, in the Northern Baja California peninsula, by evaluating (i) the levels of blue fan palm seed removal by vertebrates at two spatial scales and the initial fate of dispersed seeds, (ii) the spatial distribution and association of seedlings and adults at two spatial scales, (iii) seed removal levels and seedling densities based on density and distance to adult palm trees, and (iv) the population age structure. Overall, seed
\end{abstract}

Electronic supplementary material The online version of this article (doi:10.1007/s11258-009-9682-4) contains supplementary material, which is available to authorized users.

E. V. Wehncke $(\bowtie)$

Biodiversity Research Center of the Californias,

San Diego Natural History Museum, 1788 El Prado,

San Diego, CA 92101, USA

e-mail: elisabetw@ecologia.unam.mx;

lizwehncke@gmail.com

X. López-Medellín

Centro de Investigaciones en Ecosistemas, UNAM,

Morelia, Mexico

E. Ezcurra

UC Institute for Mexico and the United States,

Univestity of California, Riverside, CA 92521-0147, USA removal levels were low at all sites, varied at regional but not at local scales, with small rodents apparently being responsible of most removals. Adult density and distribution differed among oases, but seedling densities did differ locally. Whereas seed removal did not vary with distance from seed sources or parent trees, a weak positive association between seedlings and adults at the whole patch level indicated that establishment tended to occur in or near those grid cells where adults had established successfully. However, the analysis showed a negative association between seedling and adult densities within the patches, indicating that within the grid cells where growth was most successful, seedlings established preferentially in relatively open spaces. All life-history categories were adequately represented within each site and populations seemed to be in a fairly good conservation state. We did not find evidence to establish that post-dispersal seed removal by rodents is a main factor defining the recruitment patterns in these oases. In contrast, the effect of flood pulses seems to be significant and may have strong and conclusive effects on palm seedling distributions. We suggest that local biotic (nurse plants) and/or abiotic (canyon physiography, nurse objects) factors at each particular canyon have the potential to affect post-dispersal seed removal activity patterns by rodents, as well as to provide vital protection for palm seedling establishment from the extreme floods. This baseline information will help in further investigations on the possible mechanisms that sustain 
palm populations at their distribution limits and in stressful environments.

Keywords Coryphoideae $\cdot$ Palms ·

Plant distribution patterns - Rodents .

Seedling recruitment $\cdot$ Spatial association

\section{Introduction}

In most large arid areas of the world, the sparse vegetation cover is commonly arranged in space as a mosaic of vegetated and non-vegetated areas (Valentin et al. 1999). Within this mosaic, desert oases and riparian ecosystems form dense and luxuriant patches of vegetation (Ezcurra et al. 1988, 2006; Felger et al. 1992; Feng et al. 2006). High available moisture and other associated microclimatic conditions in desert oases and washes allow biotic communities to thrive providing refuge, food source, and safe corridors for several desert animals (Skagen et al. 1998; Feng et al. 2006). In the desert regions of the northern part of the Baja California Peninsula (Mexico), oases are mainly populated by blue fan palms (Brahea armata S. Watson) and California fan palms (Washingtonia filifera (Linden) H. Wendl.), whose populations are distributed along remote desert canyons running down the slopes of the mountain backbone of this peninsula (Henderson 1964, 1971; Cornett 1989; Franco-Vizcaíno et al. 2007). Surrounded by desert plains, these ecosystems harbor relict vegetation that was once distributed more widely during the moister Pleistocene glaciations, and are now largely restricted to moist desert canyons (Cornett 1985; Cornett et al. 1986; Grismer and McGuire 1993).

Some of these oases have been inhabited by humans for centuries, and their presence is recorded in monumental cave paintings (Meighan 1966; Cornett 1989; León-Portilla 1988; Crosby 1997). In spite of their archeological and ethno-biological importance, blue fan palm canyons are one of the less studied ecosystems in Mexico, possibly due to the inaccessibility of the remote canyons where they are found throughout the peninsula's rugged landscape. North of $28^{\circ} \mathrm{N}$, oases are fed by intermittent seasonal water derived from mountain runoff (Henderson 1971; Franco-Vizcaíno et al. 2007). In particular, the endemic blue fan palm ( $B$. armata; the most dominant palm species at these latitudes) seems well adapted to this environment, coping well with extreme aridity, summer heat, high direct solar radiation, and freezing temperatures $\left(-12^{\circ} \mathrm{C}\right.$, www.floridata.com) with only minor foliage damage. Age estimates, using repeated photography methodology (Bullock and Heath 2006), suggest a potential longevity that exceeds 500 years. Brahea armata is included in the Coryphoideae, one of the five monophyletic subfamilies of the Arecaceae (Uhl and Dransfield 1987; Dransfield et al. 2005). While most palm lineages are currently widespread in the tropical and subtropical regions of the world, in congruence with the traditional association of the family with warm and moist climates (Corner 1966; Bjorholm et al. 2005, 2006), the geographical pattern of coryphoid species richness still seems to reflect its ancestral history, exhibiting a strong bias toward Central and North America and reflecting its boreotropical dispersion route (Bjorholm et al. 2006). Thus, coryphoid species richness seems to be least strongly controlled by the modern environment, but strongly influenced by historical and regional factors (Bjorholm et al. 2006).

Since plants are structurally dominant in most terrestrial ecosystems and determine, to a large extent, the biotic and abiotic interactions within an ecosystem, vegetation characteristics are commonly used to define spatial units (Hulme and Kollmann 2005). In particular, palm oases are distributed as distinct patches in space and time and, therefore, seed dispersal and post-dispersal seed predation processes both within and between oases are of great demographic importance (Wehncke et al. 2009). For example, spatial variation in seed predation may arise because some habitats, irrespective of seed availability, are more suitable for certain granivores than others (Hulme and Benkman 2002). Part of the interest of scaling seed removal processes lies in its links to major theoretical concepts in ecology and evolution, among them density-dependent predation and species abundance and diversity as suggested by the Janzen-Connell hypothesis (Wright 2002; Hulme and Kollmann 2005). On the contrary, because the seed dispersal syndrome of Brahea fruits seems to correspond to endo-zoochory probably performed by the now extinct Pleistocene mega-fauna (R. Felger, pers. comm.), the spatial distribution of blue fan palms and their ecological interactions with the 
present-day fauna are important elements in understanding the recruitment patterns of this species near the northern limit of the family's distribution in western North America. This idea is plausible in light of the immense fauna of large animals that once roamed North America, distributed many tropical and temperate fruits, and then disappeared during the Pleistocene (Kurtén and Anderson 1980; Webb 1983; Janis 1993; Janis et al. 2004; Tiffney 2004; Zaya and Howe 2009; Johnson 2009). This hypothesis is supported by the presence of several blue fan palm characteristics that seem unfit to the living fauna; such as investing in defenses against non-existent browsers and producing fruits with extremely hard seeds that accumulate below trees. Janzen (1986) suggested that after the megafauna extinction, plants would contract to monospecific stands, each species surviving only where habitat conditions are ideal for it and where it is not exposed to resource competition from others.

Post-dispersal seed predation by animals is often considered to be the major cause of mortality throughout the life cycle of plants and one of the principal processes underlying plant recruitment patterns (Janzen 1970; Schupp 1990; Hulme 1993; Manson et al. 1998; Wenny 2000; Packer and Clay 2003). While some studies show the effect of soil pathogens near parental plants in reducing the survival of conspecific seedlings (Packer and Clay 2003), others have focused on the distinct effects of invertebrates and vertebrates on seed survival and plant communities (Notman and Villegas 2005). The role of post-dispersal seed predation per se in shaping plant recruitment patterns has also been explored via mathematical modeling (Nathan and Casagrandi 2004; Adler and Muller-Landau 2005). Mari et al. (2008) have recently introduced a spatially explicit model that incorporates the effects of different movement strategies of foragers on post-dispersal seed predation and plant establishment patterns. These authors confirmed that invertebrates are often distance-responsive, specialized seed predators that generally generate patterns conforming to the Janzen-Connell model, whereas vertebrates, typically mobile and generalist consumers generate other kind of patterns (Hammond and Brown 1998, and references therein).

In addition to biological processes, such as seed dispersal and seed predation that act upon a population having a particular range of action, the physical structure of a system has its own spatial characteristics (Dungan et al. 2002), which influence population density and distribution. For example, flood regimes in rivers of arid regions determine groundwater conditions, and declines in flood intensity and frequency may change abiotic and biotic conditions within a floodplain, homogenize seed banks, and drive patch dynamics (Pickett and White 1985) producing well-defined vegetation patterns (Stromberg et al. 1996). The presence of surface attributes, rock fragments and soil properties are key elements in shaping water, nutrient, and seed fluxes that, in turn, influence ecosystem structure and dynamics (Poesen and Lavee 1994; Aguiar and Sala 1999; Maestre and Cortina 2002; Munguía-Rosas and Sosa 2008; Peters et al. 2008). As a consequence, spatial patterns in many desert plant populations and communities derive from the interplay of abiotic factors and of positive (facilitation) and negative (competition, predation, herbivory) interactions (Fonteyn and Mahall 1981; Callaway 1995; Miriti et al. 1998, 2001). Blue fan palm desert oases are probably one of such fluctuating environments in which seeds may be dispersed in two or more "phases," with a different type of dispersal agent involved during each one. Thus, the spatial distribution of plants offers clues to understand the underlying processes that regulate plant populations and structure communities (e.g., Greig-Smith and Chadwick 1965; Janzen 1970; Connell 1971; Mack and Harper 1977; Wright and Howe 1987; Miriti et al. 1998).

Since blue fan palms are distributed in patches along canyons, a hierarchical patch structure approach (different spatial scales of analysis) of adult and seedling distributions is critical to identify the particular biotic and abiotic mechanisms involved in seed movement and palm recruitment patterns. Based on an exploratory approach and to evaluate the ecological processes underlying present day distribution and structure of blue fan palm populations, we evaluated (i) the spatial variation in seed removal by vertebrates, and the initial seed fate, (ii) the spatial distribution and association of seedlings and adults at two spatial scales, (iii) seed removal levels and seedling density based on density and distance to adult palm trees, and (iv) population age structure within three oases in northern Baja California, located widely apart and surrounded by contrasting deserts in animal and plant 
distributions, as well as climate conditions. Since seed predator communities may diverge in accordance with regional climate and biogeography (Brown 1975; Brown et al. 1979; Lawlor 1983; Wiggins 1999), we expected regional differences in post-dispersal seed predation and seed fate. Within each oasis, we explored the distribution patterns of the palms, with the expectation that these patterns may offer some preliminary clues for the identification and scaling of critical underlying mechanisms driving palm establishment and distribution in these highly fluctuating ecosystems. Since such riparian ecosystems provide vital ecological services for human and nonhuman life (Wehncke et al. 2009), the identification of these processes is cruciala for sustaining biodiversity and water availability in desert regions in the face of ongoing environmental change.

\section{Materials and methods}

\section{Study sites and species}

We studied three blue fan palm oases in three different mountain washes (San Pedro Mártir [SPM]; Cataviña [CAT], and La Libertad [LL]) separated from each other approximately $200 \mathrm{~km}$ in a straight line (Fig. 1). Phytogeographically, the sites are found in two different subdivisions of the Sonoran Desert: the San Pedro Mártir site is located within Forrest Shreve's (1951) Lower Colorado Valley, and Cataviña and La Libertad are located within Shreve's Vizcaíno Region, also known as the Central Desert of Baja California.

Along the canyons in each of the three study sites, we established four plots of approximately 1 ha in size $(200 \times 50 \mathrm{~m})$ in San Pedro Mártir and La Libertad, and two plots of 2 ha in size $(400 \times 50 \mathrm{~m})$ in Cataviña. In each site, plots were located $>30 \mathrm{~m}$ and $<3 \mathrm{~km}$ apart. Plots at San Pedro Mártir were located on the east margin of the escarpment facing the Sea of Cortés and along El Berrendo canyon $\left(30^{\circ} 32.351^{\prime} \mathrm{N}, 115^{\circ} 08.565^{\prime} \mathrm{W}\right.$; elevations: 689-769 m). Sierra San Pedro Mártir is composed of large granite blocks that drop off sharply toward the eastern desert floor below. A number of eastflowing streams flow along the escarpment fed by water collected in the higher elevations during the moist winter months. The other two oases, Cataviña and La Libertad, are part of the Natural Protected Area Valle de los Cirios and are located on the Pacific slope of the Baja California ranges. Plots in Cataviña were located along the San Antonio canyon $\left(29^{\circ} 45^{\prime} \mathrm{N}\right.$, $114^{\circ} 40^{\prime} \mathrm{W}$; elevations: $609-617 \mathrm{~m}$ ), and those in La Libertad along El Toro canyon $\left(28^{\circ} 20^{\prime} \mathrm{N}, 113^{\circ} 41^{\prime} \mathrm{W}\right.$; elevations: $402-428 \mathrm{~m}$ ). All three sites show considerable seasonal variations in rainfall (Bullock 2003), and two periods of rain are evident, one in winter (November-April), and the other in late summer (August-October). Usually the driest period is from late spring through summer (May-September). The Cataviña site, in the Central Desert region, receives around 110-150 $\mathrm{mm}$ of annual rainfall (Bullock 2003), while in the more southward La Libertad site, which is also nearer to the Gulf of California, winter precipitation is less abundant but summer tropical storms can bring considerable precipitation into the mountains.

Blue fan palms, the dominant tree species in the three study sites, are endemic to the northern part of the Baja California peninsula and the neighboring Ángel de La Guarda Island (Felger and Joyal 1999). They occur in the lower parts of canyons with subsurface flow and scattered across granite rocky slopes (Bullock and Heath 2006), and seem to be tolerant to moderate salty soils (Wehncke, pers. obs.). Of the three tribes within the subfamily Coryphoideae, the Corypheae are the least specialized and with more primitive leaf forms, flowers, and pollen (Dransfield et al. 1990; Henderson 2002). Bullock and Heath (2006) reported a maximum height of $18.9 \mathrm{~m}$ for B. armata, at Misión de Santa María, in Cataviña, though reproductive maturity can occur when these slow-growing plants reach ca. 2-m height. Flower clusters consist of many small whitish bisexual blossoms that appear in multiple branching inflorescences up to 5-m length (Roberts 1989; Henderson 2002). The one-seeded rounded fruits are of medium size $(2.0-2.5 \mathrm{~cm})$, have relatively little mesocarp, and are brownish black when mature (Roberts 1989; Henderson et al. 1995). As the fruits develop and ripen, they undergo a variety of color changes during the different pheno-phases, from green to yellow, from yellow to orange, and finally, to brownish black, when frugivore activity is maximum (Wehncke et al. 2009). There is a diverse array of present-day blue fan palm seed dispersers, such as coyote, desert fox, lynx, and several bird species that 


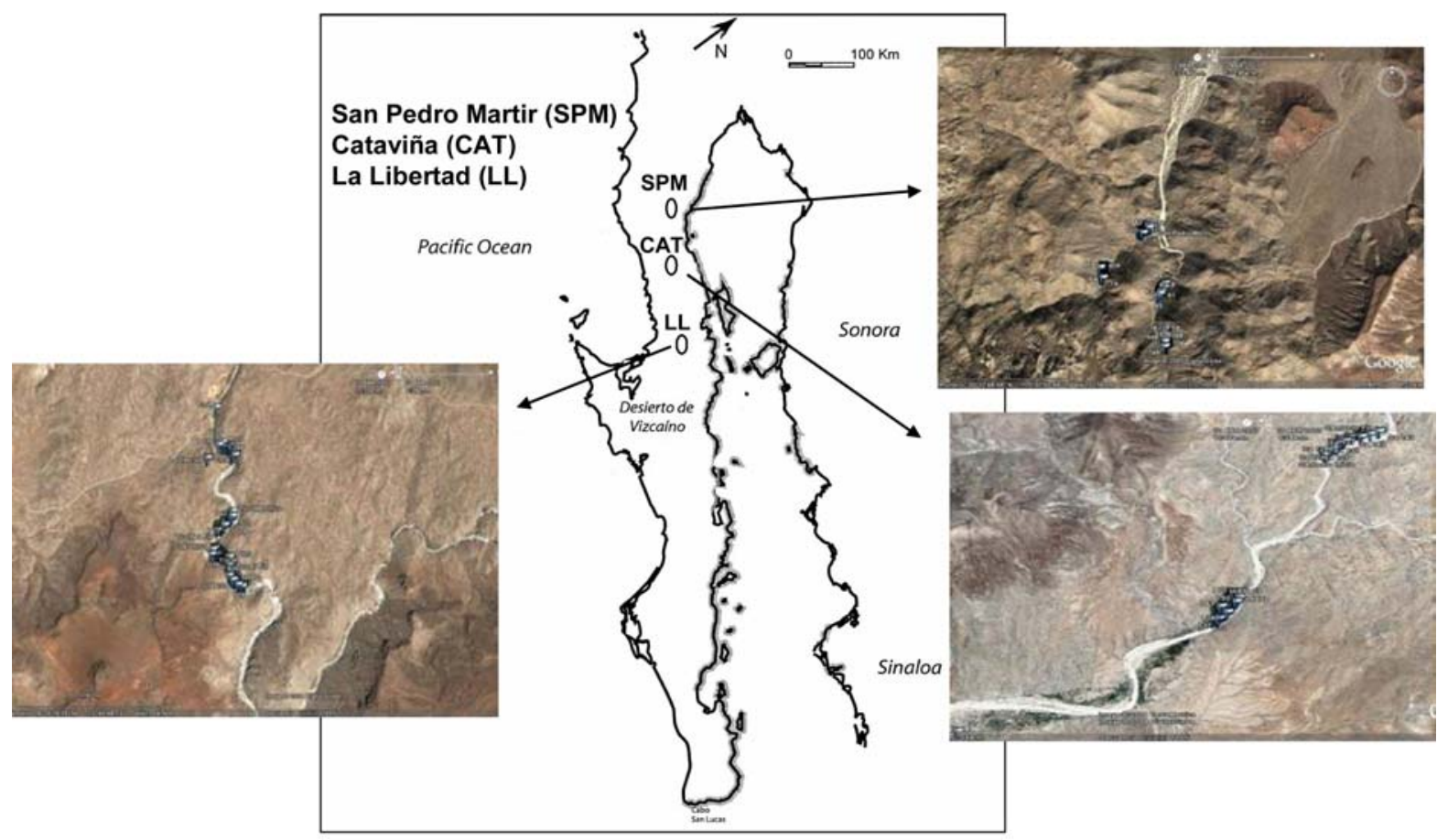

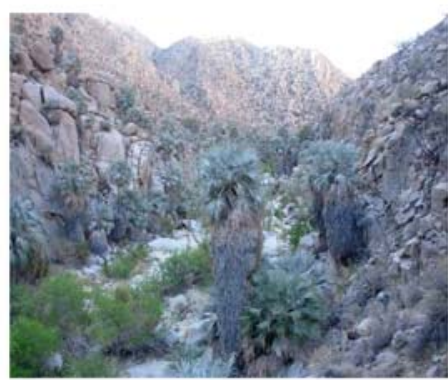

San Pedro Mártir

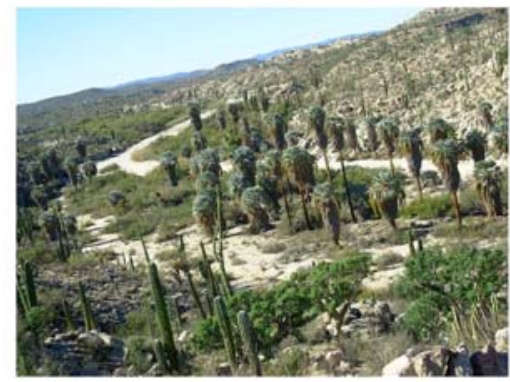

Cataviña

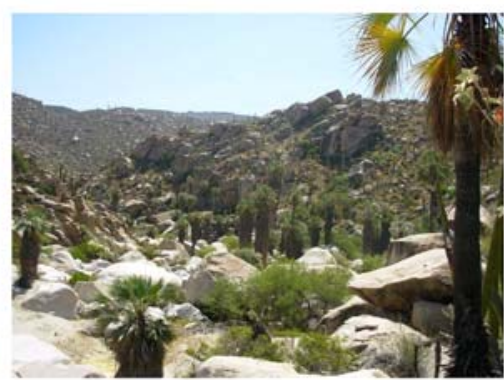

La Libertad

Fig. 1 Location of study sites (San Pedro Mártir, Cataviña, and La Libertad), and detailed Google-earth images and pictures of study plots established within sites, in northern Baja California, Mexico

consume the thin and sweet mesocarp (Wehncke et al. 2009). Fallen fruits are also subject to abrasion from sand and gravel in washes and to weathering from high direct solar radiation that can detach the thin mesocarps from the seeds.

\section{Post-dispersal seed removal experiment}

In order to evaluate spatial variation in seed removal by vertebrates and the initial fate of blue fan palm removed seeds, we selected two of the established plots at San Pedro Mártir, two at Cataviña, and three at La Libertad for seed removal experiments. Within these plots, we established stations for seed removal experiments (40 stations per plot at CAT, totaling 80 stations; 10 stations per plot at SPM, totaling 20 stations; and 10 stations per plot at LL, totaling 30 stations). Stations were set as follows: a transect was laid within each plot, and at every $10 \mathrm{~m}$ along it, two stations were set according to two randomly selected directions among six possibilities (north-east, east, south-east, south-west, west, and north-west direction). Once both directions were selected, each station was finally set at a distance randomly selected between 0 and $15 \mathrm{~m}$ from the original transect. The distance of $15 \mathrm{~m}$ corresponds to the limit of the plot area at each transect's side. The smaller number of stations in San Pedro Mártir and La Libertad was a 
result of the lower fruit production observed at these sites (during a 2-year study period), and also due to the difficulty of climbing these inaccessible canyons for repeated seed removal monitoring. Minimum distances between stations resulted in $8-10 \mathrm{~m}$, approximately.

Four blue fan palm seeds were placed at each station, totaling 320, 80, and 120 seeds in Cataviña, San Pedro Mártir, and La Libertad, respectively. Only ground-collected seeds that had lost the fleshy mesocarp were used in this experiment. The original experimental design considered the possible differences between large and small vertebrate seed predators and, therefore, to exclude large vertebrate's effect, two seeds were left exposed and two were placed inside a $20-\mathrm{cm}$ diameter, $15-\mathrm{cm}$ tall, wiremesh exclosure with 4-cm mesh size at each station, and treatments were placed at approximately 0.5$1.0 \mathrm{~m}$ apart. Seeds were tagged with a $30-\mathrm{cm}$-long nylon thread of two contrasting colors, according to the treatment, to facilitate their subsequent proper detection. We intended to measure spatial variation in vertebrate seed removal by considering possible differences between small rodent removal levels (for those seeds which were excluded from large vertebrates) and vertebrate seed removal levels by large and small vertebrates together (using data for exposed seeds). This additive effect experimental design resulted from the logistical difficulty of isolating the effect of large vertebrates from that of small rodents. Thus, we expected two possible results: (1) Less seed removal from treatments excluded from larger predators, or, alternatively, and (2) similar seed removal levels in both treatments. The first possibility would suggest a measurable effect of large vertebrates added to the effect of small rodents (or that small vertebrates preferred to harvest seeds outside the cages). The second would suggest that the effect of large vertebrates is negligible compared with that of small rodents. During three consecutive days, we registered the number of seeds left at each station ( 0,1 , or 2 seeds found), the distances at which seeds were removed and their status (alive, dead, or missing) after inspecting a 5-mradius area around each station. Because of the logistic limitation to effectively separate the effects of large and small vertebrates, and given the fact that we found no significant differences in seed removal levels between treatments in each of the three sites, we finally took the decision of pooling the seed removal data.

Since all the three sites showed considerable seasonal variations in rainfall (Bullock 2003), and during the time blue fan palms were in fruit (EW unpublished phenological data), seeds were placed at different times in each site: in mid-September of 2006 in Cataviña, at the end of March 2007 in San Pedro Mártir, and at the beginning of April 2007 in La Libertad. These periods corresponded to the height of fruiting season of palms in each site. We used an ordinal logistic regression to evaluate whether seed removal at the end of the experiment differed among sites, plots, and the exclusion treatments. The dependent categorical ordinal variable was "seeds left or not removed" with three response categories $(0,1,2,3$, and 4 seeds left), and the categorical independent variables were "sites" (SPM, CAT, and LL), "plots" nested inside sites (two, two and three different plots inside SPM, CAT, and LL, respectively), and "treatment" (seeds excluded versus exposed). Vertebrate blue fan palm seed predator species registered during the studied period and oases were checked with the literature (Ceballos and Oliva 2005) and detailed in the supplementary appendices.

A search for the colored threads of removed seeds was made to enable us measure the removal distances and calculate the percentages of seeds that were found alive, dead, or missing in all areas. Removed seeds were classified as "alive" if they were found intact or buried; as "dead" if the thread was found, but not the seed, and as "missing" whether neither the thread nor the seed could be found. Although, the two latter categories could also be considered as postdispersed seeds, we based our classification on Price and Joyner (1997), who stated that desert rodents often consume seeds directly as they are collected instead of storing them in caches. We evaluated whether the proportions of live, dead, or missing seeds were similar or not among sites using a Chisquare test of independence.

Local and regional patterns of seedling and adult palm distributions

In order to assess adult distributions and seedling densities among plots and sites, and to evaluate the effect of adult distributions on seed permanence and seedling density patterns, we used the nearest- 
neighbor method (Thomas et al. 2002). We determined the distribution of adults in plots by measuring conspecific adult densities and nearest-neighbor distances (NNDs) from 128 randomly placed points or stations. Random points used in the previous seed removal experiment were used as the center of the area for seedling and adult censuses. We defined conspecific adult density (AD) as the number of conspecific adult palms found within an area of 10-m radius of random points (area $0.03 \mathrm{ha}$ ), and NND as the distance between each random point and the first nearest adult conspecific (Thomas et al. 2002). We registered adult densities by classifying data into three categories $(0=$ no adults, $1=$ one adult, and $2=$ more than one adult within $10 \mathrm{~m}$ ), as well as, NNDs $(1=$ nearest adult within $0-5 \mathrm{~m}, 2=$ within 5-10 $\mathrm{m}$, and $3=$ at $>10 \mathrm{~m}$ ). For this analysis, we arbitrarily classified as adults all palms that beared observable reproductive structures, while all plants with no observable reproductive parts, smaller than approximately one or two meters were classified as seedlings (sensu lato, as the category may include morphological seedlings but also juveniles). In order to evaluate seedling density in relation to $\mathrm{AD}$ and NND, we censused palm seedlings within an area of $1.5-\mathrm{m}$ radius of each previously used random points (area $7.07 \mathrm{~m}^{2}$ ). Based on natural seedling distributions observed in oases, we established three seedling density categories, $(0=$ no seedling, $1=$ one seedling, and $2=$ more than one seedling). In order to have a measure of removal activity in relation to $\mathrm{AD}$ and NND, we considered the total number of seeds that remained at each station (unmoved seeds) at the end of the seed removal experiments described previously. We arbitrarily used the term "seed survival" to name the seeds that were not removed from their original place, though we recognize that removed seeds could also have been post-dispersed and survived. We considered five seed permanence or survival categories for analyses $(0,1,2,3$, and 4 seeds). Based on logistic regressions, we explored whether AD, NND, and seedling density varied among three different areas and seven different plots. We then used chi-squared analyses to explore the blue fan palm recruitment pattern by testing the associations of seedling density with AD and NND, and of seed survival with AD and NND for all sites together and separately for each site.

\section{Population structure}

In order to obtain a picture of the structure of blue fan palm populations, we selected a total of seven plots of variable sizes within the three study areas (Table 1), in which a total of 310 reproductive adults and 1,190 non-reproductive individual palms (juveniles distributed in four categories) were geo-referenced, tagged, and measured. For this part of the study, we established a more rigorous classification of life stages and size categories: All plants with no observable above-ground stem were classified as seedlings (S); plants with observable trunks up to 0.2-m height were classified as small juveniles (SJ); plants with trunks $0.2-1 \mathrm{~m}$ as juveniles $(\mathrm{J})$; trunks

Table 1 Blue fan palm individuals registered at all plots within study sites

\begin{tabular}{|c|c|c|c|c|c|c|c|}
\hline \multirow[t]{2}{*}{ Sites } & \multirow[t]{2}{*}{ Plot } & \multirow[t]{2}{*}{ Sampled area (ha) } & \multicolumn{5}{|c|}{ Categories (no. of individuals standardized at 1 ha) } \\
\hline & & & $\mathrm{S}$ & SJ & $\mathrm{J}$ & LJ & A \\
\hline \multirow[t]{4}{*}{ SPM } & Bepal1 & 1 & 64 & 68 & 36 & 9 & 42 \\
\hline & Bepal2 & 1 & 176 & 67 & 55 & 12 & 67 \\
\hline & Beci2 & 0.5 & 208 & 64 & 40 & 32 & 84 \\
\hline & Beci1 & 0.75 & 138 & 21 & 17 & 11 & 96 \\
\hline LL & TNA2 & 1 & 18 & 35 & 28 & 15 & 28 \\
\hline \multirow[t]{2}{*}{ CAT } & Sta Inez & 0.6 & 508 & 157 & 45 & 12 & 52 \\
\hline & San Antonio & 2 & 26 & 18 & 3 & 4 & 15 \\
\hline Totals & & 6.85 & 1139 & 430 & 224 & 94 & 384 \\
\hline
\end{tabular}

Size-age categories seedlings $(S)$, small seedlings $(S J)$, juveniles $(J)$, large juveniles $(L J)$, and adults $(A)$. Study sites San Pedro Mártir $(S P M)$, La Libertad $(L L)$, and Cataviña (CAT). Spatial layout of plots Bepal1, Bepal2, and TNA2 $(200 \times 50 \mathrm{~m})$, Beci2 $(100 \times 50 \mathrm{~m})$, Beci1 $(150 \times 50 \mathrm{~m})$, Sta. Inez $(120 \times 50 \mathrm{~m})$, and San Antonio $(400 \times 50 \mathrm{~m})$ 
from 1-3 m with no observable reproductive parts as large juveniles (LJ); and all plants with trunks $>3 \mathrm{~m}$ as adults (A, in the field all these plants are also reproductive; see supplementary information). Densities of reproductive adults were also estimated for all 12 plots.

Spatial analysis of adult palms and seedlings distributions

\section{Adult and seedling sampling}

We evaluated the spatial patterns of blue fan palm adults and seedlings in the same plots used for the population structure analyses, and at two different spatial scales, selected to identify the possible biotic and/or abiotic underlying processes involved in palm recruitment and distribution patterns, which could be difficult to observe at just one scale. In order to convert location information to count data, all plots were divided into grids of $5 \mathrm{~m} \times 5 \mathrm{~m}$ contiguous cells, and the number of adult palms and seedlings were counted in each cell unit. The $25 \mathrm{~m}^{2}$ cell size was chosen according to Dungan et al. (2002) and based on the spatial characteristics of the processes under study (frugivory and predation activity), as well as because this grid size includes on average ca. one individual tree per cell (Perry and Dixon 2002).

\section{Spatial scales of analysis}

The two spatial scales of our study were (a) the "patch" scale (approximately 1-ha plot), represented by the average size of naturally distributed single patches found along canyons, and (b) the "withinpatch" scale, restricted to cell units having at least one adult tree. By removing the contrast among areas with and without trees, this method effectively reduced the scale studied to that of the individual palm tree. The within-patch pattern with only grid cells including adult plants may have different clustering indices as the between-patch pattern, and may yield important information on local spatial dynamics (Perry and Dixon 2002). However, by removing empty cells that do not contain adults, it is association, not spatial pattern per se, that is the focus of the analysis. Thus, any apparent positive association between adults and seedlings found at larger scales may be distinguished from local distribution patterns within patches (Perry and Dixon 2002).

\section{Evaluating the spatial distribution pattern of adults and seedlings}

Spatial patterns of both adults and seedlings were analyzed using the Spatial Analysis by Distance Indices methodology (SADIE vers.1.22; Perry 1998; Perry et al. 1999), developed explicitly for the spatial analysis of ecological data in the form of counts. The analysis of spatial patterns by SADIE involves the distance to regularity $(D)$, which measures the total distance needed to pass from the observed spatial arrangement of counts (count refers to the measured discrete value of a variable under study) to a regular arrangement where all units have the same value of the variable under study. SADIE uses a transportation algorithm (Kennington and Heldason 1980) to calculate $D$, and usually, as the value increases, aggregation of data also does. In order to assess its magnitude, $D$ was compared with the corresponding values from randomizations where the counts were arranged randomly among the sample units. Thus, we obtained a formal test of randomness and an index of aggregation (Ia) resulting from the division of the observed value of $D$ by the mean value from randomizations. Usually an aggregated variable has an $I a>1$, a spatially random variable has an $I a=1$, and a regular distributed variable has an $I a<1$. Counts were randomly arranged and the proportion of values in the frequency distribution that were as large as or larger than the observed value of $D$ was calculated. After a two-tailed test and with $\alpha=0.05$, a data set had an aggregated pattern if $P<0.05$, a random pattern if $P$ was between 0.05 and 0.95 , and a regular pattern if $P>0.95$.

The overall measure of spatial aggregation $(I a)$ is a good measure of the general spatial pattern of a data group, but may fail to encompass all the facets of spatial pattern in an arrangement. Another index, the clustering index $(v)$, quantifies the degree to which the count for each sample unit contributes to the overall degree of clustering, either as a part of a patch (areas with above-average density) or a gap (areas with below-average density). Thus, for example, for a donor unit $i$ (sampling point with aboveaverage abundance) having a flow of counts to $n_{j}$ receiver units (sampling points with below-average 
abundance), the average distance of outflow is $Y_{i}$ (see Perry et al. 1999). Then, the SADIE procedure calculates an average outflow distance for each of the donor units. The value of $Y_{i}$ is a good indicator of clustering since it tends to be larger for a unit that is part of a patch than for one with an isolated large count with relatively small number of neighbors. By convention, sampling points with large values of $v_{i}$ $(>1.5)$ are within patches, and sampling points with large and negative values of $v_{j}(<-1.5)$ are within gaps. Values close to unity indicate a random placement of that unit. Again, by employing randomizations in which the observed counts are permuted among the sample units, an index of clustering is ascribed to each sample unit. In these tests, the mean value of the clustering index over the patch units $\left(V_{i}\right)$ and the mean value over the gap units $\left(V_{j}\right)$ were compared with its expectation of 1 and -1 , respectively (their corresponding values for randomizations). The values of the clustering indices are continuous and may be mapped, interpolated, and contoured, facilitating the identification and measurement of size, location, and proximity to other clusters.

\section{Evaluating spatial association between adults and seedlings distributions}

We assessed the spatial relationship between adults and seedlings by comparing the spatial properties of each data set (the index of clustering $v$ previously obtained) so that spatial features that match between the sets contribute to association and those that mismatch contribute to dissociation. We obtained an overall spatial association index $X$ (the simple correlation coefficient between the clustering indices of each set) and measures of local association $\left(X_{p}\right)$ for each unit, which may then be mapped, and contoured (Perry and Dixon 2002). Assessments of the significance of $X$ were tested against values of $X_{\text {rand }}$ from randomization tests (we used 1,000 randomizations in all analyses). Critical values and limits were estimated for $X$ under the null hypothesis of no association, from centiles of the randomization distribution, $X_{\text {rand }}$. For a recommended two-tail test with, say, a size of $5 \%$ the probability level should be less than 0.025 for significant association or greater than 0.975 for significant dissociation. The significance of the randomization test was later corrected for the presence of small-scale spatial autocorrelation (Perry and Dixon 2002) and each critical value inflated by a scale factor using the method of Dutilleul (1993). The process involves detrending each set if necessary and then calculating the corrected degrees of freedom for correlation. Thus, an effective sample size that takes into account the degree of autocorrelation in data was calculated. Large values of local association are indicated by the coincidence of a patch cluster for one set with a patch cluster for the other, or by the coincidence of two gaps; dissociation is indicated by a patch coinciding with a gap. Measures of local association $X_{p}$, and critical values and limits for $X_{p}$ may also be plotted to visualize critical contours in maps of local association.

\section{Results}

Post-dispersal seed removal experiment

After pooling data, using the total number of seeds set at each station (4 seeds/station), and without considering treatment effects, patterns of seed removal were significantly different among the three sites $\left(\chi^{2}=10\right.$, df $=2, P=0.007)$, but not between plots inside these sites $\left(\chi^{2}=4.5\right.$, df $\left.=4, P=0.3\right)$. Results suggest spatial variation in seed removal levels at regional but not at local scales, and also that small rodent seem to be responsible of most seed removal in all sites during the time of study (Fig. 2a).

Overall, most of the seeds were not removed from their original site in all areas (in $78 \%$ of cases, seeds were found intact, $7 \%$ corresponded to cases in which one half of the seeds was removed, and $15 \%$ to cases where both seeds were removed, $N=256$ ). Plots from La Libertad (LL) showed the highest seed removal followed by those from San Pedro Mártir and Cataviña (43\% of cases with all or 1 seed(s) removed in LL compared with $0.1 \%$ of these cases in the other two sites; Fig. 2a). From a total of 87 removed seeds in all areas, $36 \%$ were found intact, $42 \%$ were considered dead, and $22 \%$ were missing seeds. The fate of removed seeds was significantly different among the three sites $\left(\chi^{2}=21.7\right.$, df $=2$, $P=0.0002$; Fig. 2b). Whereas Santa Inez plot in Cataviña showed the lower values of seed removal, $48 \%$ of these removed seeds were dead, and $28 \%$ 
Fig. 2 Patterns of seed removal: a percentages of cases with zero, one, two, three, and four seeds left at each site and plots within sites. San Pedro Mártir $(S P M)$ included beci2 and bepal2 plots, Cataviña $(C A T)$ included San Antonio ( $s a$ ) and Santa Inez (si) plots, and La Libertad $(L L)$ included ta2, tna1, and tna2 plots, $\mathbf{b}$ range of distances (meters) of blue fan palm seed removal by vertebrates (using the method of colored threads) and percentage of cases in which removed seeds were missing, dead or alive in each site
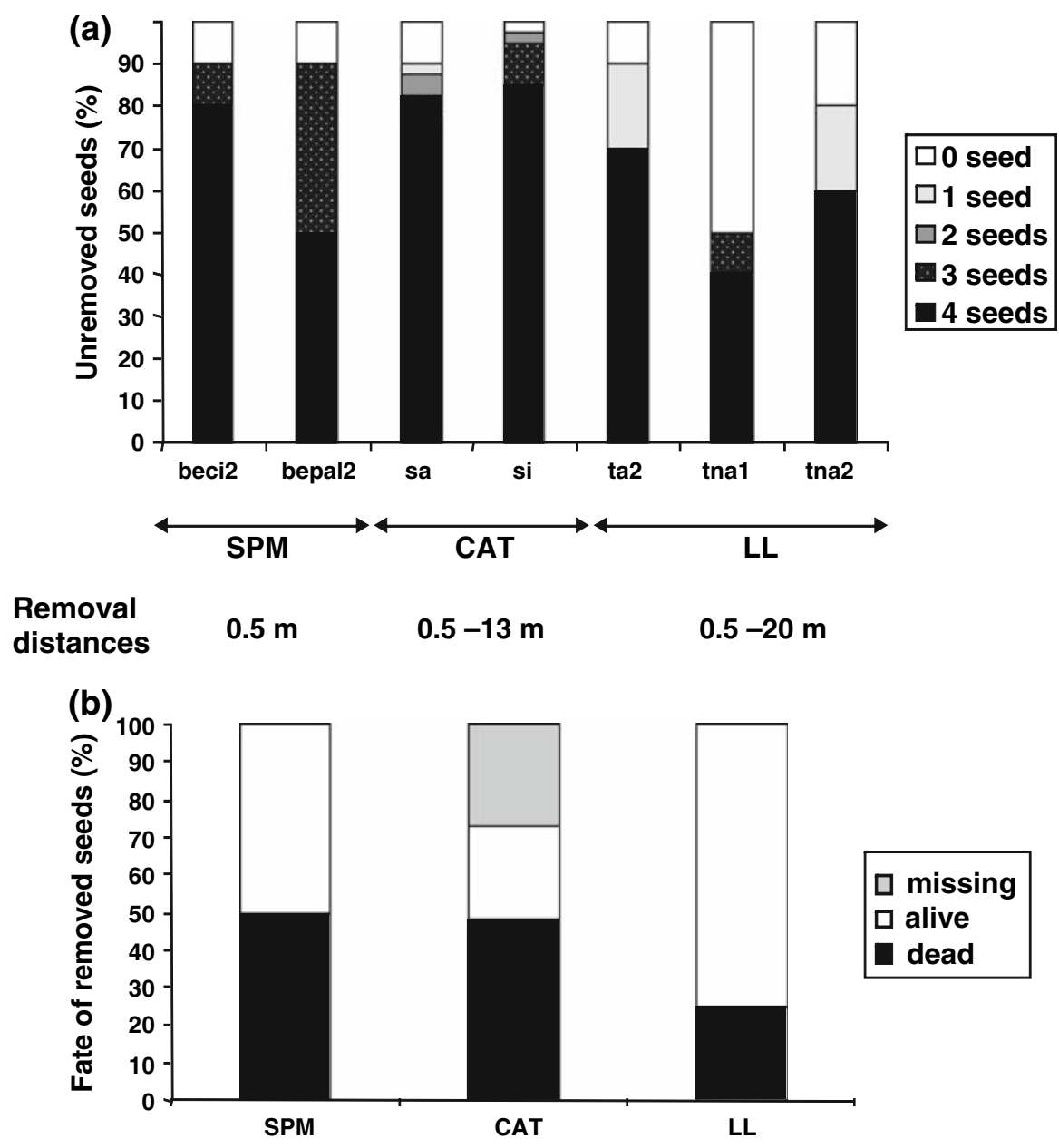

were missing ( $N=69$; Fig. 2a, b). By contrast in La Libertad $75 \%$ of removed seeds were alive and only $25 \%$ were dead $(N=16)$. Seeds were removed from 0.5 up to $20 \mathrm{~m}$ from the stations in La Libertad and from 0.5 up to $13 \mathrm{~m}$ in Cataviña, $1 \mathrm{~m}$ being the most frequent removal distance at both canyons (Fig. 2b). Only two seeds were found after removal at San Pedro Mártir; they were removed to a distance of $0.5 \mathrm{~m}$ from the origin. Seeds were normally found below bushes and/or rock caves.

Local and regional patterns of adult and seedling palm distributions

The three sites showed differences in adult palm distributions; $\mathrm{AD}$ and NND differed among sites $\left(\chi^{2}=26.8, \mathrm{df}=2, P<0.00001 ; \chi^{2}=52.6, \mathrm{df}=2\right.$, $P<0.00001$, respectively; $N=128$ data points in both cases), but differences were not significant among plots nested within sites $\left(\chi^{2}=8.4, \mathrm{df}=4\right.$, $P=0.07$, for $\mathrm{AD}$; and $\chi^{2}=7.6$, df $=4, P=0.1$, for $\mathrm{NND)}$. In general, ADs, measured at random points, increased as NND decreased (Fig. 3a, b). Results from the nearest-neighbor conspecific method, showed that Cataviña had the lowest AD (range: 03 adults within $0.03 \mathrm{ha}$ ) and the highest NNDs measured from randomly placed points (range: $0.3-$ $33 \mathrm{~m}$ ); La Libertad represented the intermediate case (AD: 1-4 adults within 0.03 ha; NND: $0.1-4.5 \mathrm{~m}$ ); and San Pedro Mártir showed the highest ADs and the most aggregated adult palm distribution (1-6 adults within 0.03 ha; NND: 0.1-4 m; Fig. 3a, b). Differences in plots were homogeneously distributed within their corresponding sites, though plots from Cataviña seemed to differ from the other two sites (Fig. 3a, b). San Pedro Mártir and La Libertad had a 
significantly greater number of random points with two or more adult palms within an area of $10-\mathrm{m}$ radius (SPM: $90 \%$ of cases, $N=28$; LL: $85 \%$ of cases, $N=20$; CAT: $45 \%$ of cases, $N=80$ ). These two sites also showed $100 \%$ of cases with nearest neighbors clumped less than $5 \mathrm{~m}$ away. In contrast, this highly clumped category was observed in only $45 \%$ of random points in Cataviña (Fig. 3a, b). Although the significances for plots nested within sites were only marginally significant, in this last, less dense, site relatively large inter-plot differences were also observed; adults from the San Antonio plot seemed to be even less aggregated than those from Santa Inez (only $30 \%$ of 40 cases corresponded to AD $>1$ adult within a 10-m radius in San Antonio; while $60 \%$ of 40 cases corresponded to $\mathrm{AD}>1$ in Santa Inez). Since adult palm densities in San Pedro Mártir doubled those of La Libertad and Cataviña, it is not strange that the number of adults within a $10-\mathrm{m}$ radius from random points tended also to be greater,
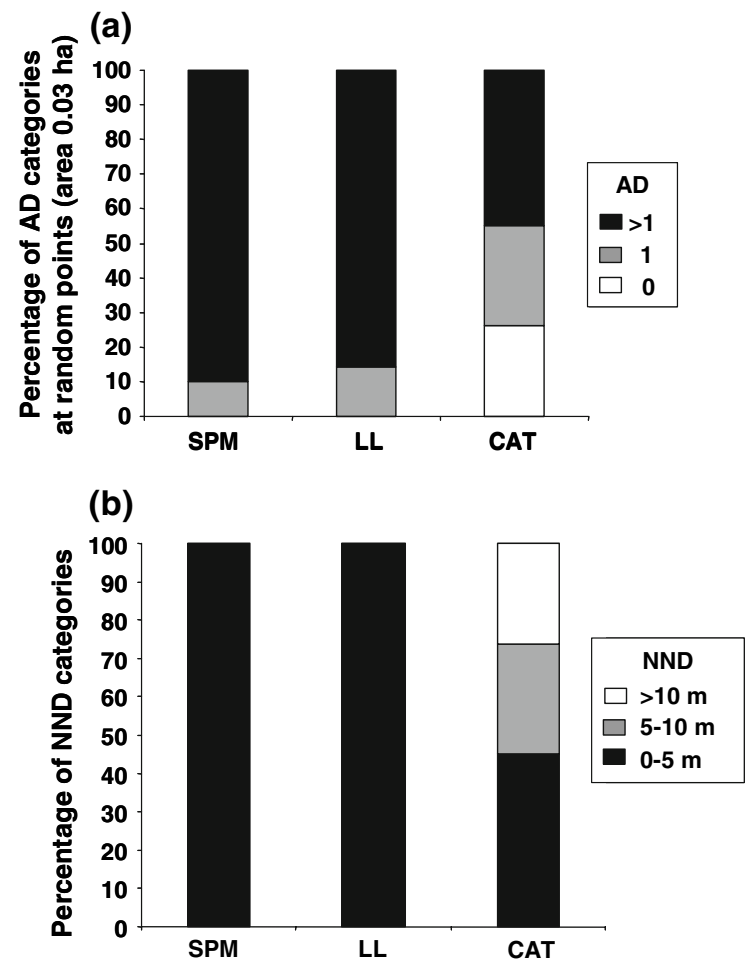

Fig. 3 Distribution patterns of adult palms in San Pedro Mártir (SPM), Cataviña (CAT), and La Libertad $(L L)$ : a percentages of each adult density category $(A D 0,1$, and $>1$ adults in a 0.03 ha area), b percentages of each nearestneighbour distance category (NND 0-5 m, 5-10 m, >10 m), measured at random points in all sites and the distances to nearest-neighbor shorter, in this first canyon.

In contrast with adult distributions, seedling densities were only marginally different among sites $\left(\chi^{2}=6.1, \mathrm{df}=2, P=0.05\right)$, but markedly different among plots within sites $\left(\chi^{2}=24.8, \quad \mathrm{df}=4\right.$, $P=0.0001)$. The highest seedling densities were registered in the Bepal2 and Beci2 plots in San Pedro Mártir, and in the Santa Inez plot in Cataviña.

Seedling density and seed survival in relation to adult distributions

Results from the NND method applied at all sites together showed that maximum seedling densities occurred at an AD category of more than one adult within an area of $10-\mathrm{m}$ radius $\left(\chi^{2}=12.6, \mathrm{df}=4\right.$, $P=0.01$; Fig. $4 \mathrm{a})$, and at nearest neighbor category of $0-5 \mathrm{~m}\left(\chi^{2}=10, \mathrm{df}=4, P=0.04\right.$; Fig. $\left.4 \mathrm{~b}\right)$. When individual sites were tested separately, the trend was significant in all the three, but quantitatively more marked in San Pedro Mártir and La Libertad, where seedlings were only found when the
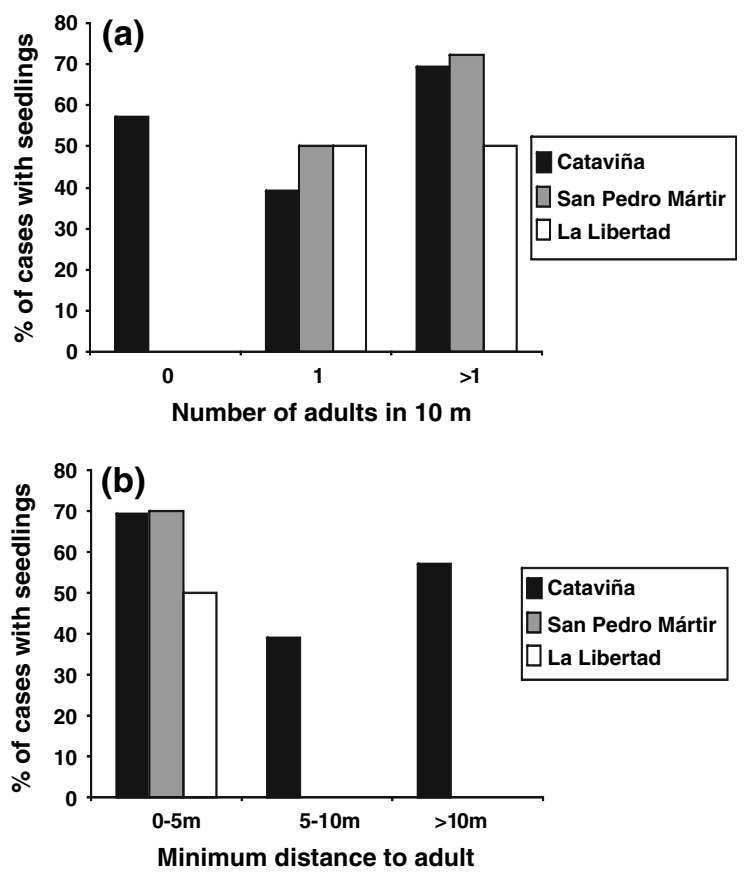

Fig. 4 a Percentages of random points with seedlings (area $0.0007 \mathrm{ha})$, for each adult density category $(A D 0,1$, and $>1$ adults), b at each nearest-neighbor distance category (NND 0$5 \mathrm{~m}, 5-10 \mathrm{~m},>10 \mathrm{~m}$ ), in San Pedro Mártir, Cataviña, and La Libertad 
random points fell in dense palm areas or, similarly in areas where the nearest adult palm was less than $5 \mathrm{~m}$ away (Fig. 4a, b). In contrast, survival of seeds was neither significantly associated with $\mathrm{AD}\left(\chi^{2}=7.2\right.$, $\mathrm{df}=8, P=0.5)$, nor with the distance to the nearest neighbor $\left(\chi^{2}=10.3\right.$, df $\left.=8, P=0.3\right)$.

Blue fan palm population structure

Study sites had a similar population age structure with no marked differences in the relative abundance of demographic categories per plot (Table 1; Fig. 5). In the seven plots analyzed, all blue fan palm populations followed an inverse " $\mathrm{J}$ " distribution, a pattern that is very common in long-lived plants, with a high number of seedlings (S), a lower frequency of individuals of intermediate sizes, and relatively high numbers of the long-lived adults. However, some differences arose among study sites when adult and non-reproductive individual densities were compared; the plots from San Pedro Mártir had the highest densities of adults while Santa Inez in Cataviña showed the highest density of seedlings (Table 1). Taking into consideration the number of adults in all the plots and sites together, estimations of total ADs for San Pedro Mártir was three times higher than those of the other two sites (SPM: 75 palms/ha; LL: 28; CAT: 24).

Spatial analysis of adult palms and seedlings distributions

The spatial distribution of both adults and seedlings tended to show a clumped pattern $(I a>1)$ in all the
Fig. 5 a Number of blue fan palm individuals per hectare at each age category, b distribution of age categories (percentages of each category per plot) in study plots and sites. San Pedro Mártir (SPM): Bepal1, Bepal2, Beci2, Beci1 plots; La Libertad $(L L)$ : TNA2 plot; and Cataviña $(C A T)$ : Santa Inez and San Antonio plots (a)
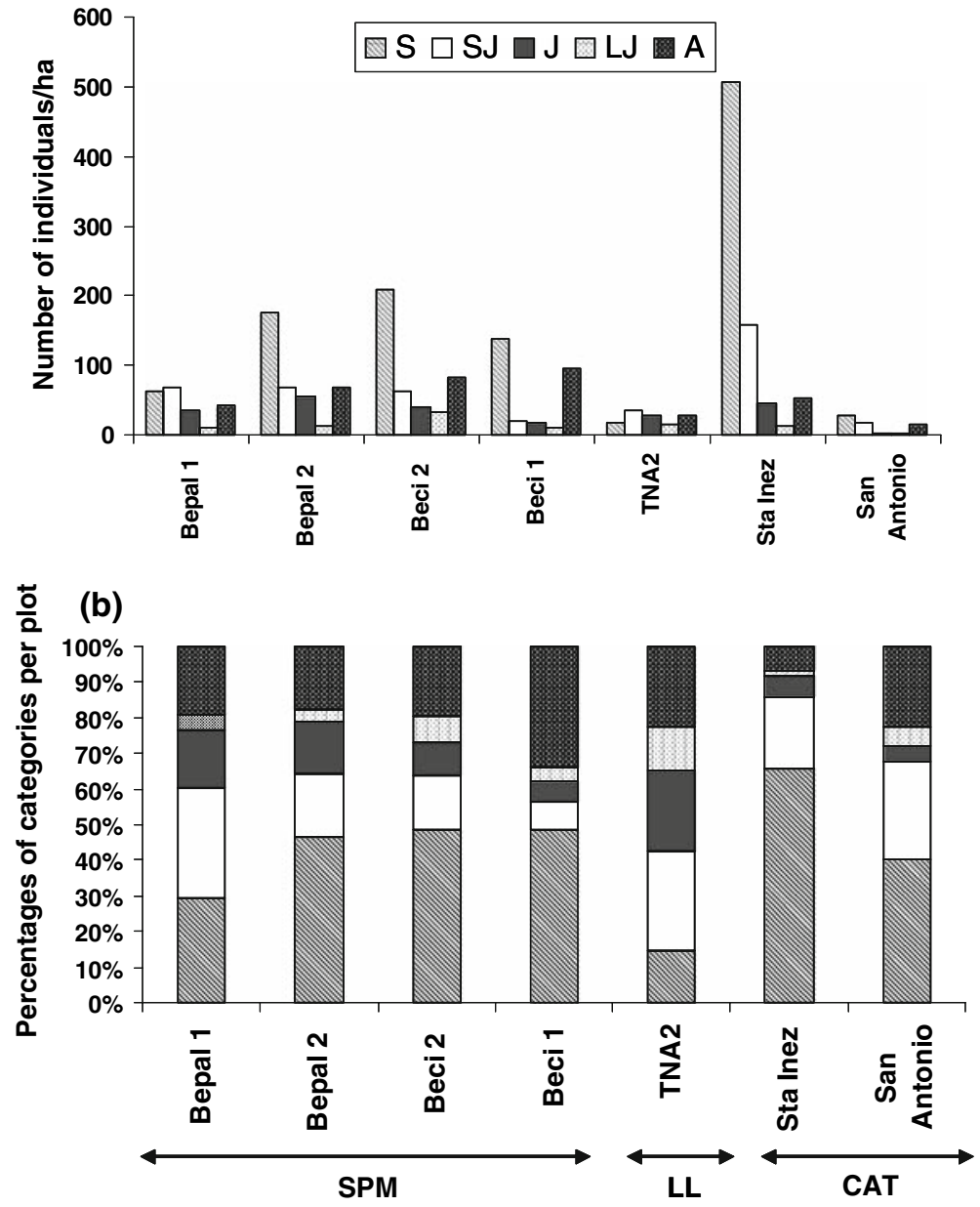
Table 2 SADIE index and probabilities $(P)$ of blue fan palm adults and seedlings, at two spatial scales ("patch" and "withinpatch"), for the three study sites, Cataviña, La Libertad and San Pedro Mártir

\begin{tabular}{|c|c|c|c|c|c|c|}
\hline Scales & Sites & Study plot (size) & & $I a(P)$ & $n$ & $X(P)$ \\
\hline \multirow[t]{4}{*}{ Patch } & CATAVIÑA & SI 2 (0.65 ha) & Adults & $1.29(0.05)$ & & $0.15(0.05)$ \\
\hline & & & Seedlings & $1.72(0.0005)$ & 263 & \\
\hline & & SA $\mathrm{T}$ (1.5 ha) & Adults & $1.47(0.07)$ & & $0.18(0.02)$ \\
\hline & & & Seedlings & $1.26(0.15)$ & 605 & \\
\hline \multirow[t]{4}{*}{ Within-patch } & & SI 2 (0.2 ha) & Adults & $1.56(0.008)$ & & $-0.44(>0.99)$ \\
\hline & & & Seedlings & $1.44(0.02)$ & 63 & \\
\hline & & SA T (0.2 ha) & Adults & $2.1(0.009)$ & & $-0.58(>0.99)$ \\
\hline & & & Seedlings & $1.2(0.21)$ & 81 & \\
\hline \multirow[t]{4}{*}{ Patch } & LIBERTAD & TNA1 (1 ha) & Adults & $0.9(0.7)$ & & $0.3(<0.01)$ \\
\hline & & & Seedlings & $2.2(0.0003)$ & 275 & \\
\hline & & TNA2 (1 ha) & Adults & $0.74(0.96)$ & & $0.1(0.06)$ \\
\hline & & & Seedlings & $1.5(0.03)$ & 556 & \\
\hline \multirow[t]{4}{*}{ Within-patch } & & TNA1 (0.2 ha) & Adults & $3.02(0.0003)$ & & $-0.9(>0.99)$ \\
\hline & & & Seedlings & $3.1(0.0003)$ & 49 & \\
\hline & & TNA2 (0.2 ha) & Adults & $1.02(0.4)$ & & $-0.7(>0.99)$ \\
\hline & & & Seedlings & $0.8(0.7)$ & 74 & \\
\hline \multirow[t]{4}{*}{ Patch } & SP MARTIR & Bepal 2 (1 ha) & Adults & $1.4(0.07)$ & & $0.15(0.02)$ \\
\hline & & & Seedlings & $4.3(0.0003)$ & 444 & \\
\hline & & Beci 2 (0.5 ha) & Adults & $0.99(0.4)$ & & $0.09(0.07)$ \\
\hline & & & Seedlings & $4.6(0.0003)$ & 488 & \\
\hline \multirow[t]{4}{*}{ Within-patch } & & Bepal 2 (0.2 ha) & Adults & $3.5(0.0003)$ & & $-0.5(>0.99)$ \\
\hline & & & Seedlings & $3.4(0.0003)$ & 134 & \\
\hline & & Beci 2 (0.2 ha) & Adults & $3.5(0.0003)$ & & $-0.9(>0.99)$ \\
\hline & & & Seedlings & $4.1(0.0003)$ & 97 & \\
\hline
\end{tabular}

Ia spatial aggregation index (in bold significant aggregation patterns), $n$ total number of counts, $X$ overall spatial association index between adults and seedlings (in bold significant dissociation patterns)

cases (Table 2), both when all cells within each plot were considered and when only cells with at least one adult were taken into account (the "patch" and "within-patch" treatments in Table 2). Noticeably, the distribution of seedlings and of adults within patches in San Pedro Mártir was in general more strongly clumped than in the other two sites. We also found a positive, but weak, association index $(X>0)$ between adults and seedlings in all the three sites, but this association was lost when the analysis was done only within patches, and a general negative association pattern $(X<0)$ emerged (Table 2$)$.

\section{Discussion}

Despite the logistic difficulty of completely isolating the effect of large vertebrates, these results suggest that small rodents were responsible for most of the blue fan palm seed removal at the time of the experiment. This is congruent with the lack of observable large vertebrates that could be interested in predating such hard seeds. On the contrary, spatial variation in seed removal levels was significant at regional but not at local scales. These three oases are located wide apart and surrounded by contrastingly distinct deserts and climate regimes, suggesting that regional differences in post-dispersal seed predation and seed fate registered here could have arisen as a result of distinct seed predator communities (Brown 1975; Brown et al. 1979; Lawlor 1983; Wiggins 1999). For example, some rodent species that are found in the hot, sandy desert of extreme northeastern Baja California (the Lower Colorado Valley) are incapable of penetrating the rocky hills just south and west of San Felipe (Lawlor 1983). However, since we 
registered approximately similar species composition of seed removers at all the three sites (Appendix in ESM), we suggest that regional differences in postdispersal seed removal and seed fate might rather result from distinct removal activity and behavior at each site as a result of differences in the physical characteristics of the three canyons. Although logistic limitations in this study could have contributed in some extent to the observed spatial variation, other similar studies suggest that spatial variation in seed predation may arise because some habitats, irrespective of seed availability, are more suitable for certain granivores than others (Hulme and Benkman 2002). Although granite rocks were the most salient structural and geological characteristics shared by these oases, the physiography of canyons was quite different. Cataviña was characterized by wide canyons with less coverage of understory plants and/or rocks, thus affording rodents with limited hiding places and, thus, making them more visible and thus susceptible to predators. Such effect has the potential to restrict rodent movement patterns, and consequently seed removal activities. Cataviña showed the lowest seed removal values (Fig. 2a); though most of the seeds removed disappeared or were considered dead (Fig. 2b). Frequently fewer seeds are removed from open microhabitats (Myster and Pickett 1993; Hulme 1997), and this appears to occur when rodents are the principal granivores, since their abundance is positively associated with vegetation cover (Hulme 1993). Factors determining post-dispersal seed removal may frequently overlap between spatial scales (Hulme and Kollmann 2005). Factors influencing seed removal at the microhabitat scale (ranging from 0.01 to $10 /$ $100 \mathrm{~m}^{2}$, or the individual tree level) include microtopography, soil characteristics, rocks, dead woods, ground cover, and fruiting plants; those at the level of the habitat scale $\left(10-10,000 \mathrm{~m}^{2}\right)$ include vegetation height and cover, seed availability, predator avoidance, and microclimate (Hulme and Kollmann 2005). Although there is a lack of consistent trends across the many studies published to date, one of the major source of variation in seed removal seems to be vegetation structure. Thus, structural differences within the same type of habitat or microhabitat may explain at least some of the contradictions in the literature (Hulme and Kollmann 2005).

Apart from rodents (Appendix in ESM), other potentially important seed removers are birds such as woodpeckers; they were commonly seen storing blue fan palm fruits and seeds inside tree holes and might probably be considered a potential seed remover. Several other large vertebrates such as gray and desert foxes, ring tails, raccoons, coyotes, and felids consume blue fan palm fruits and disperse their seeds intact (Wehncke et al. 2009). Since it is suggested that desert rodents harvest and consume recently produced seeds compared to those already stored in the seed bank (Price and Joyner 1997), we suggest that most of the missing seeds might have probably been consumed and not post-dispersed by rodents. We acknowledge that removed seeds should be followed to their ultimate demise or successful germination and establishment to effectively understand the details of seed fate and plant recruitment (Vander Wall et al. 2005). However, in long-lived plant species for which germination times are extended (or even unknown), seed predation estimations from previous studies in similar habitats are useful, at least, as an exploratory approach. Seed removal values and distances were lower in Cataviña (up to $13 \mathrm{~m}$ ) than in La Libertad (up to $20 \mathrm{~m}$ ); based on this, and the wide open canyons characteristic of this location, we speculate that rodents in Cataviña could have probably preferred other more accessible species instead of taking the risk of removing blue fan palm seeds from the middle of the canyon. For instance, in a semiarid ecosystem of Chile, it has been shown that small mammals foraged more extensively under shrubs than in open microhabitats (Kelt et al. 2004), as well as some bird species faced differences in predation risk under shrubs and in open habitats, both from terrestrial predators (e.g., foxes, felids; Pulliam and Mills 1977) and aerial predators (e.g., raptors; Lima et al. 1987; Lima 1992, 1993). Aerial predators of rodents and birds registered in blue fan palm oases include the great-horned owl (Bubo virginianus), Harris's hawk (Parabuteo unicinctus), Zone-tailed hawk (Buteo albonotatus), Red-tailed hawk (B. jamaicencis), Red-shouldered hawk (B. lineatus), and the Common black hawk (Buteogallus anthracynus). Terrestrial predators include the Eastern spotted skunk (Spilogale putorius), badgers (Taxidea taxus), gray and kit foxes (Urocyon cineroargenteus and Vulpes macrotis, respectively), coyotes (Canis latrans), felids (Puma concolor and Lynx rufus), and different species of rattle snakes. Thus, although granivore predation was not directly 
evaluated here, it seems plausible that the geomorphologic characteristics of each of the studied canyons, as well as the distribution of the vegetation cover, have the potential to affect post-dispersal seed removal activity by rodents and/or birds.

Although the three blue fan palm populations studied showed marked regional differences in ADs and distributions, seedling densities were marginally different among sites, but markedly dissimilar among plots located within these sites. Although there is a general belief that the micro-environmental conditions prevailing in shaded microhabitats are the main factor that enhances seed germination, nurse objects such as rocks and channel bars may exert a significant protecting effect to palm seedlings from the extreme pulsing stream flow in these canyons. It has been reported, at least, for some cacti species, that longevity and growth were the highest for seedlings placed next to rocks (Peters et al. 2008). Spatial association of cacti with objects has also been described by other studies finding different mechanisms between plant and object facilitation (Munguía-Rosas and Sosa 2008). While both types of microhabitats were suitable for columnar cactus seed germination, nurse plants mainly favored seedling survivorship while nurse objects favored seed permanence (Munguía-Rosas and Sosa 2008). In arid and semiarid climates, and particularly in desert blue fan palm oases where precipitation can be flashy (sudden, erratic, intense, and of short duration), channels are susceptible to extensive erosion (EW, pers. obs.). Such disturbances often remove large amounts of streamside vegetation and sometimes remove entire adult palms, produce abrupt depositional changes (EW, pers. obs.), and disrupt community propagules banks (Briggs 1996). Thus, any biotic or nurse object, sensu Mungía-Rosas and Sosa (2008), providing protection against mechanical damage and/or sand accumulation in such changing ecosystems might enhance palm seedling survival and finally determine seedling distribution pattern. Future studies should focus on the dependence of palm seedling establishment on local biotic and/or abiotic factors such as nurse plants or objects, as well as on soil moisture, humidity, and geomorphology.

Results from the nearest-neighbor method used to evaluate seedling density and seed permanence or survival in relation to adult distributions showed that seedlings tend to establish near adults and their densities decline with distance from the adult palm. This tendency was significant at all the sites. In contrast, seed survival showed no significant association with adult densities or distance to the nearest neighbor, showing no variation in differential survival attributable to distances to adults. Based on this and the overall low levels of blue fan palm seed removal by vertebrates found in all the sites, it seems that current post-dispersal seed removal by vertebrates does not have a significant effect on blue fan palm establishment. A similar pattern emerged from the SADIE methodology. A weak positive association between seedlings and adults at the whole patch level simply indicates that establishment tends to occur in or near those grid cells where adults have already established successfully. More importantly, however, was that the analysis showed a negative association between seedlings and adults within the patches, indicating that within the grid cells where growth is most successful seedlings established preferentially in relatively open spaces. In short, from both the nearest neighbor and the SADIE analysis, we can conclude that there was no real tendency for adults and seedlings to occur together at a local scale. Their apparent affinity at the scale of the whole patch is probably caused by their co-occurrence in particular patches where local conditions are more suitable, possibly related to water availability. Flood pulsing is a mechanism that structures and connects riparian plant communities via flood dispersal (Naiman et al. 1993; Middleton 2000) and drives metacommunity dynamics in deserts (Boudell and Stromberg 2008). It has been shown that flood pulsing disperses propagules into a variety of microenvironments, many with inappropriate moisture conditions, and that some seed species may escape local extinction by persisting in the propagules bank until flood pulsing creates moisture conditions that are more suitable (Leck and Brock 2000; Boudell and Stromberg 2008). Although blue fan palm seed dispersal by vertebrates is significant in these oases (Wehncke et al. 2009), large-scale flood pulsing might produce important homogenization of floodplain propagules banks (Boudell and Stromberg 2008). Seed species may thus be transported across the floodplain into a variety of microsites and species arrayed along some environmental gradient (such as water gradients in riparian ecosystems, Naiman et al. 2005), according to their life-history traits and strategies. Thus, the 
temporal scale at which all these processes occur should significantly influence palm seedling establishment and distributions.

A variety of recruitment patterns have been described in nature (McCanny 1985; Nathan and Casagrandi 2004) which have critical roles in the early developmental stages of plant populations and on the diversity of plant communities (Howe 1986; Fleming and Estrada 1993; Tilman 1994; Hurtt and Pacala 1995; Clark et al. 1999; Hubbell et al. 1999), though most of them have been reported for tropical areas. From the point of view of the patch scale, the pattern observed here would seem to fit the "invariant survival pattern" (McCanny and Cavers 1987) in which establishment declines monotonically but seed survivorship does not vary with distance from seed sources or parent trees. This recruitment pattern is commonly attributable to mobile and generalized predators that feed at varying distances from the seed source (McCanny and Cavers 1987; Augspurger and Kitajima 1992; Notman et al. 1996). However, viewed at the within patch scale in which seedlings distributed irrespective of adults and considering a recent study that found significant pre-dispersal seed predation by beetles below palm trees in Cataviña (Wehncke et al. 2009), we suggest that the "exact compensation pattern" (McCanny and Cavers 1987) should also be considered in blue fan palm oases. This recruitment pattern is characterized by an increase of seed survival with distance but an invariant seedling establishment. Ultimately, the recruitment pattern of blue fan palms in desert oases will probably depend on the relative importance and occurrence of seed dispersal and seed predation processes versus abiotic processes at distinct temporal and spatial scales. Whether dispersal via hydrochory is of key importance in this ecosystem, temporal dynamics may provide windows of opportunity for palm establishment as extant conditions may change due to flood pulse-driven patch dynamics (sensu Pickett and White 1985). Though at a very low degree, anthropic disturbance (e.g., off-road activities, tourism, and cattle ranching), other than seed predation by rodents could also be operating at these scales and having additional influences on seedling recruitment and distribution.

It seems that geomorphology and the associated water regime might be significant on the palm population structure of these oases. In this sense, it is noteworthy that in the San Pedro Mártir site-a deep narrow canyon with steep walls-adult palm density was the highest, while in the flat arroyo wash of Cataviña-an open sandy area with lots of available space and the formation of mid-channel bars that provide safe sites for seedling establishment - total palm seedling densities were the highest of the three sites. Bar formations have important influences in the life cycle of many riparian plant species (Briggs 1996). Bars, generally composed of sand and/or gravel, are largely determined by the stream flow and influence the geometry strength of flow (Heede 1980). Overall, and judging by their population structure where all life-history categories were adequately represented within each site, the blue fan palm populations in the three oases seemed to be in a fairly good conservation state.

The exploration and scaling of seed removal and blue fan palm distribution patterns was important to help identify potential factors that might be significant in their establishment, and suggest future directions of research. In order to conclude, although overall levels of post-dispersal seed removal were low in all sites, at present small rodents and invertebrates (Wehncke et al. 2009) were identified to be responsible for blue fan palm seed removal/ predation in this ecosystem. Nevertheless, seeds may escape from predation near seed sources due to considerable levels of seed dispersal by vertebrates (Wehncke et al. 2009), as well as the homogenizing effect of the stream flow. Based on our observations, the effect of flood pulse in this ecosystem is likely to have strong effects on the canyon geomorphology, erosion, and depositional patterns of sediments. The presence of nurse plants and/or nurse objects, as well as the canyon physiography at each site may have the potential to affect post-dispersal seed removal activity patterns by rodents, as well as to provide vital protection for palm seedling establishment from the extreme flood pulsing. More evidence on the levels at which these processes might be affected by biotic and/or abiotic factors are needed to better understand their weight in the distributions of blue fan palms. In a stressful desert location of California, seedling micro-environment was shown to be more important to seedling survival and growth than seed size or maternal environment (Breen and Richards 2008). Boudell and Stromberg (2008) suggest that plants species whose seeds are transported across the 
floodplain into a variety of microenvironments with varying environmental conditions will respond to flood pulse-driven metacommunity dynamics according to their life-history traits and strategies. Here, we found no real tendency for adults and seedlings to occur together when patterns were analyzed at a local scale. At the scale of the whole patch, an apparent affinity between seedlings and adults arose, probably explained by their co-occurrence in particular patches where local conditions are more suitable, possibly related to water availability, and this is common for several riparian systems in which communities are arranged along some environmental or water gradient (Hupp and Osterkamp 1996; Naiman et al. 2005).

Dominant plants provide habitat and ecosystem structure, and act as the source of multiple interactions with the present-day fauna, and so, changes in their distributions can be expected to have cascading effects on the entire ecosystem. Plants with megafauna fruit syndromes in Central and North America typically have distributions restricted to lowlands and flood plains, reflecting their current reliance on gravity and water to move abrade large seeds (Janzen and Martin1982; Barlow 2000). In many vegetation communities, anachronistic plants seem to be heading toward a long-term decline (Johnson 2009). In order to understand living plant communities, we need to understand present-day processes by imagining them with their Pleistocene megafauna. Understanding desert oases dynamics and the mechanisms that sustain them will help to support biodiversity and identify the dispersal pathways that will serve as baseline for future management policies in ecosystems that depend on uncertain climatic events.

Acknowledgments This research was funded by the Institute of International Education and the Alcoa Foundation fellowship awarded to E.W. and by The David and Lucile Packard Foundation granted to E.E. We greatly appreciate the support of the BRCC at the San Diego Natural History Museum and of Joe Perry, who provided us with SADIE software. We are grateful to the local people living around oases in all the three sites, especially to Don Hexiquio Mendoza, Oscar Valdez, and Antonio López, and to V Sánchez Sotomayor at Valle the los Cirios Protected Area, CONANP, Mexico, for all the support given during the study. We also want to thank, R Felger for giving us several insights on this ecosystem and for the review of an earlier version of this manuscript. We are also grateful to S. Bullock, M. Salazar, and M. T. Pulido for their help.
Open Access This article is distributed under the terms of the Creative Commons Attribution Noncommercial License which permits any noncommercial use, distribution, and reproduction in any medium, provided the original author(s) and source are credited.

\section{References}

Adler FR, Muller-Landau HC (2005) When do localized natural enemies increase species richness? Ecol Lett 8:438447

Aguiar MR, Sala OE (1999) Patch structure, dynamics and implications for the functioning of arid ecosystems. Trends Ecol Evol 14:273-277

Augspurger CK, Kitajima K (1992) Experimental studies of seedling recruitment from contrasting seed distributions. Ecology 73:1270-1284

Barlow C (2000) The ghosts of evolution. Basic Books, New York

Bjorholm S, Svenning J-C, Skov F, Balslev H (2005) Environmental and spatial controls of palm (Arecaceae) species richness across the Americas. Glob Ecol Biogeogr 14:423-429

Bjorholm S, Svenning J-C, Baker W, Skov F, Balslev H (2006) Historical legacies in the geographical diversity patterns of New World palm (Arecaceae) subfamilies. Bot J Linn Soc 151:113-125

Boudell JA, Stromberg JC (2008) Flood pulsing and metacommunity dynamics in a desert riparian ecosystem. J Veg Sci 19:373-380

Breen AN, Richards JH (2008) Irrigation and fertilization effects on seed number, size, germination and seedling growth: implications for desert shrub establishment. Oecologia 157:13-19

Briggs MK (1996) Riparian ecosystem recovery in arid lands. Strategies and references. The University of Arizona Press, Tucson

Brown JH (1975) Geographical ecology of desert rodents. In: Cody ML, Diamond JM (eds) Ecology and evolution of communities. Harvard University Press, Cambridge, pp 315-341

Brown JH, Reichman OJ, Davidson DW (1979) Granivory in desert ecosystems. Ann Rev Ecol Syst 10:201-227

Bullock SH (2003) Seasonality, spatial coherence and history of precipitation in a desert region of Baja California peninsula. J Arid Environ 53:169-182

Bullock SH, Heath D (2006) Growth rates and age of native palms in the Baja California desert. J Arid Environ 67:391-402

Callaway RM (1995) Positive interactions among plants. Bot Rev 61:306-349

Ceballos G, Oliva G (2005) Los mamíferos silvestres de México. CONABIO, Fondo de Cultura Económica, Mexico

Clark JS, Silman M, Kern R, Macklin E, HilleRisLambers J (1999) Seed dispersal near and far: patterns across temperate and tropical forests. Ecology 80:1475-1494 
Connell JH (1971) On the role of natural enemies in preventing competitive exclusion in some marine animals and in forest trees. In: den Boer PJ, Gradwell GR (eds) Dynamics of populations. Centre for Agricultural Publishing and Documentations, Wageningen, pp 298-312

Corner EJH (1966) The natural history of palms. Weidenfeld and Nicolson, London

Cornett JW (1985) Reading fan palms. Nat Hist 94:64-73

Cornett JW (1989) Desert palm oasis. Palm Springs Desert Museum, Palm Springs

Cornett JW, Glenn T, Stuart JM (1986) The largest desert fan palm oases. Principes 30:82-84

Crosby HW (1997) The cave paintings of Baja California. Sunbelt Publications, San Diego

Dransfield J, Ferguson IK, Uhl NW (1990) The coryphoid palms: patterns of variation and evolution. Ann Mo Bot Gard 77:802-815

Dransfield J, Uhl NW, Asmussen CB, Baker WJ, Harley MM, Lewis CE (2005) A new phylogenetic classification of the palm family, Arecaceare. Kew Bull 60:559-569

Dungan JL, Perry JN, Dale MRT, Legendre P, Citron-Pousty S, Fortin MJ, Jakomulska A, Miriti M, Rosenberg MS (2002) A balanced view of scale in spatial statistical analysis. Ecography 25:626-640

Dutilleul P (1993) Modifying the t test for assessing the correlation between two spatial processes. Biometrics 49: 305-314

Ezcurra E, Felger RS, Russell A, Equihua M (1988) Fresh water islands in a desert sand sea: the hydrology, flora, and phytogeography of the Gran Desierto oases of northwestern Mexico. Desert Plants 9(2):35-44, 55-63

Ezcurra E, Mellink E, Wehncke E, Gonzalez C, Morrison S, Warren A, Dent D, Driessen P (2006) Natural history and evolution of the world's deserts. In: Ezcurra E (ed) Global deserts outlook. United Nations Environment Programme, pp 1-26. http://www.unep.org/geo/gdoutlook

Felger RS, Joyal E (1999) The palms (Arecaceae) of Sonora, Mexico. Aliso 18:1-18

Felger RS, Warren PL, Anderson LS, Nabhan GP (1992) Vascular plants of a desert oasis: flora and ethnobotany of Quitobaquito, Organ Pipe Cactus National Monument, AZ. Proc San Diego Soc Nat Hist 8:1-39

Feng Q, Si J, Zhang Y, Yao J, Liu W, Su Y (2006) Microclimatic characteristics of the Heihe oasis in the hyperarid zone of China. J Geogr Sci 16:34-44

Fleming TH, Estrada A (1993) Frugivory and seed dispersal: ecological and evolutionary aspects. Kluwer Academic Group, The Netherlands

Fonteyn PJ, Mahall BE (1981) An experimental analysis of structure in a desert plant community. J Ecol 69:883-896

Franco-Vizcaíno E, López-Beltrán AC, Salazar-Ceseña M (2007) Water relations and community composition in three blue fan palm oases across the californian-sonoran biome transition. Southwest Nat 52:191-200

Greig-Smith P, Chadwick MJ (1965) Data on pattern within plant communities III. Acacia-Capparis semi-desert scrub in the Sudan. J Ecol 53:465-474

Grismer LL, McGuire JA (1993) The oases of Central Baja California, Mexico. Part I. A preliminary account of the relict mesophytic herpetofauna and the status of the oases. Bull Sci Calif Acad Sci 92:2-24
Hammond DS, Brown VK (1998) Disturbance, phenology and life-history characteristics: factors influencing distance/ density-dependent attack on tropical seeds and seedlings. In: Newbery DM, Prins HHT, Brown ND (eds) Dynamics of tropical communities. Blackwell, Oxford, pp 51-78

Heede BH (1980) Stream dynamics: an overview for land managers. USDA Forest Service General Technical Report RM-72. Fort Collins

Henderson R (1964) Palm hunter in the wastelands. Principes 8:14-23

Henderson R (1971) Palms of canyons of Baja California. La Siesta Press, California

Henderson A (2002) Evolution and ecology of palms. The New York Botanical Garden Press, New York

Henderson A, Galeano G, Bernal R (1995) Field guide to the palms of the Americas. Princeton University Press, Princeton

Howe HF (1986) Seed dispersal by fruit-eating birds and mammals. In: David R (ed) Seed dispersal. Academic Press, London, pp 123-189

Hubbell SP, Foster RB, O'Brien ST, Harms KE, Condit R, Wechsler B, Wright SJ, Loo de Lao S (1999) Light-gap disturbances, recruitment limitation, and tree diversity in a neotropical forest. Science 283:554-557

Hulme PE (1993) Postdispersal seed predation by small mammals. Symp Zool Soc Lond 65:269-287

Hulme PE (1997) Postdispersal seed predation and the establishment of vertebrate dispersed plants in Mediterranean scrublands. Oecologia 111:91-98

Hulme PE, Benkman CW (2002) Granivory. In: Herrera CM, Pellmyr O (eds) Palm-animal interactions. An evolutionary approach. Blackwell Science, Oxford, pp 132-154

Hulme PE, Kollmann J (2005) Seed predator guilds, spatial variation in post-dispersal seed predation and potential effects in plant demography: a temperate perspective. In: Forget PM, Lambert JE, Hulme PE, Vander Wall SB (eds) Seed fate: predation, dispersal and seedling establishment. CABI Publishing, Wallingford, pp 9-30

Hupp CR, Osterkamp WR (1996) Riparian vegetation and fluvial geomorphic processes. Geomorphology 14:277295

Hurtt GC, Pacala SW (1995) The consequences of recruitment limitation: reconciling chance, history and competitive differences between plants. J Theor Biol 176:1-12

Janis CM (1993) Tertiary mammal evolution in the context of changing climates, vegetation and tectonic events. Annu Rev Ecol Syst 24:467-500

Janis CM, Damuth J, Theodor JM (2004) The species richness of Miocene browsers, and implications for habitat type and primary productivity in the North American grassland biome. Palaeogeogr Palaeclimatol Palaeoecol 207:371398

Janzen DH (1970) Herbivores and the number of tree species in tropical forests. Am Nat 104:501-528

Janzen DH (1986) Chihuahuan desert nopaleras: defaunated big mammal vegetation. Annu Rev Ecol Syst 17:595-636

Janzen DH, Martin PS (1982) Neotropical anachronisms: the fruits the gomphotheres ate. Science 215:19-27

Johnson CN (2009) Ecological consequences of Late Quaternary extinctions of megafauna. Proc R Soc B. doi: 10.1098/ rspb.2008.1921 
Kelt DA, Meserve PL, Forister ML, Nabors K, Gutiérrez JR (2004) Seed predation by birds and small mammals in semiarid Chile. Oikos 104:133-141

Kennington JL, Heldason RV (1980) Algorithms for network programming. Wiley, New York

Kurtén B, Anderson E (1980) Pleistocene mammals of North America. Columbia University Press, New York

Lawlor TE (1983) The peninsular effect on mammalian species diversity in Baja California. Am Nat 121:432-439

Leck MA, Brock MA (2000) Ecological and evolutionary trends in wetlands: evidence from sedes and seed banks in New South Wales, Australia and New Jersey, USA. Plant Species Biol 15:97-112

León-Portilla M (1988) Historia Natural y Crónica de la Antigua California; Miguel del Barco (2nd edn). Instituto de Investigaciones Históricas, Universidad Nacional Autónoma de Mexico

Lima SL (1992) Strong preference for apparently dangerous habitats? A consequence of differential escape from predators. Oikos 64:597-600

Lima SL (1993) Ecological and evolutionary perspectives on escape from predatory attack: a survey of North American birds. Wilson Bull 105:1-47

Lima SL, Wiebe KL, Dill LM (1987) Protective cover and the use of space by finches: is closer better? Oikos 50:225230

Mack RN, Harper JL (1977) Interference in dune annuals: spatial pattern and neighborhood effects. J Ecol 65:345363

Maestre FT, Cortina J (2002) Spatial patterns of surface soil properties and vegetation in a Mediterranean semi-arid steppe. Plant Soil 241:279-291

Manson RH, Ostfeld RS, Canham CD (1998) The effects of tree seed and seedling density on predation rates by rodents in old fields. Ecoscience 5:183-190

Mari L, Casagrandi R, Gatto M, Avgar T, Nathan R (2008) Movement patterns of seed predators as determinants of plant recruitment patterns. Am Nat 172:694-711

McCanny SJ (1985) Alternatives in parent-offspring relationships in plants. Oikos 45:148-149

McCanny SJ, Cavers PB (1987) The escape hypothesis: a test involving a temperate, annual grass. Oikos 49:67-76

Meighan C (1966) Prehistoric rock paintings in Baja California. Am Antiq 31(3):372-392

Middleton BA (2000) Hydrochory, seed banks, and regeneration dynamics along the landscape boundaries of a forested wetland. Plant Ecol 146:169-184

Miriti MN, Howe HF, Wright SJ (1998) Spatial patterns of mortality in a Colorado Desert plant community. Plant Ecol 136:41-51

Miriti MN, Wright SJ, Howe HF (2001) The effects of neighbors on the demography of a dominant desert shrub (Ambrosia dumosa). Ecol Monogr 71:491-509

Munguía-Rosas MA, Sosa VJ (2008) Nurse plants vs. nurse objects: effects of woody plants and rocky cavities on the recruitment of the Pilosocereus leucocephalus columnar cactus. Ann Bot 101:175-185

Myster RW, Pickett STA (1993) Effect of litter, distance, density and vegetation patch type on postdispersal tree seed predation in old fields. Oikos 66:381-388
Naiman RJ, Decamps H, Pollock M (1993) The role of riparian corridors in maintaining regional biodiversity. Ecol Appl 3:209-212

Naiman RJ, Decamps H, McClain ME (2005) Riparia: ecology, conservation and management of streamside communities. Elsevier Academic Press, Burlington

Nathan R, Casagrandi R (2004) A simple mechanistic model of seed dispersal, predation and plant establishment: JanzenConnell and beyond. J Ecol 92:733-746

Notman EM, Villegas AC (2005) Patterns of seed predation by vertebrate versus invertebrate seed predators among different plant species, seasons and spatial distributions. In: Forget PM, Lambert JE, Hulme PE, Vander Wall SB (eds) Seed fate: predation, dispersal and seedling establishment. CABI Publishing, Wallingford, pp 55-76

Notman EM, Gorchov DL, Cornejo F (1996) Effect of distance, aggregation, and habitat on levels of seed predation for two mammal-dispersed neotropical rain forest tree species. Oecologia 106:221-227

Packer A, Clay K (2003) Soil pathogens and Prunus serotina seedling and sapling growth near conspecific trees. Ecology 84:108-119

Perry JN (1998) Measures of spatial pattern for counts. Ecology 79:1008-1017

Perry JN, Dixon PM (2002) A new method to measure spatial association for ecological count data. Ecoscience 9:133141

Perry JN, Winder L, Holland JM, Alston RD (1999) Red-blue plots for detecting clusters in count data. Ecol Lett 2: 106-113

Peters EM, Martorell C, Ezcurra E (2008) Nurse rocks are more important than nurse plants in determining the distribution and establishment of globose cacti (Mammillaria) in the Tehuacán Valley, Mexico. J Arid Environ 72:593-601

Pickett STA, White PS (1985) The ecology of natural disturbance and patch dynamics. Academic Press, San Diego

Poesen J, Lavee H (1994) Rock fragments in top soils: significance and processes. Catena 23:1-28

Price MV, Joyner JW (1997) What resources are available to desert granivores: seed rain or soil seed bank? Ecology 78:764-773

Pulliam HR, Mills GS (1977) The use of space by wintering sparrows. Ecology 58:1393-1399

Roberts NC (1989) Baja California plant field guide. Natural History Publishing Company, La Jolla

Schupp EW (1990) Annual variation in seedfall, postdispersal predation and recruitment of a neotropical tree. Ecology 71:504-515

Skagen SK, Melcher CP, Howe WH, Knopf FL (1998) Comparative use of riparian corridors and oases by migrating birds in southeast Arizona. Conserv Biol 12:896-909

Stromberg JC, Tiller R, Richter B (1996) Effects of groundwater decline on riparian vegetation of semiarid regions: The San Pedro River, Arizona, USA. Ecol Appl 6:113131

Thomas L, Buckland ST, Burnham KP, Anderson DR, Laake JL, Borchers DL, Strindberg S (2002) Distance sampling. In: El-Shaarawi A, Piegorsch WW (eds) Encyclopedia of environmetrics, vol 1. Wiley, Chichester, pp 544-552 
Tiffney BH (2004) Vertebrate dispersal of seed plants through time. Annu Rev Ecol Syst 35:1-29

Tilman D (1994) Competition and biodiversity in spatial structured habitats. Ecology 75:2-16

Uhl NW, Dransfield J (1987) Genera Palmarum. A classification of palms. Allen Press, Kansas

Valentin C, d'Herbés JM, Poesen J (1999) Soil and water components of banded vegetation pattern. Catena 37:1-24

Vander Wall SB, Forget P-M, Lambert JE, Hulme PE (2005) Seed fate pathways: filling the gap between parent and offspring. In: Forget P-M, Lambert JE, Hulme PE, Vander Wall SB (eds) Seed fate, predation, dispersal and seedling establishment. CABI Publishing, Wallingford, pp 1-8

Webb SD (1983) The rise and fall of the Late Miocene ungulate fauna in North America. In: Nitecky MH (ed) Coevolution. University of Chicago Press, Chicago, pp 267-306
Wehncke EV, López-Medellín X, Ezcurra E (2009) Patterns of frugivory, seed dispersal and predation of blue fan palms (Brahea armata) in oases of northern Baja California. J Arid Environ 73:773-783

Wenny DG (2000) Seed dispersal, seed predation and seedling recruitment of a neotropical mountain tree. Ecol Monogr 70:331-351

Wiggins DA (1999) The peninsular effect on species diversity: a reassessment of the avifauna of Baja California. Ecography 22:542-547

Wright SJ (2002) Plant diversity in tropical forests: a review of mechanisms of species coexistence. Oecologia 130:1-14

Wright SJ, Howe HF (1987) Spatial pattern and mortality in Colorado Desert perennials. Oecologia 73:543-552

Zaya DN, Howe FH (2009) The anomalous Kentucky coffeetree: megafaunal fruit sinking to extinction? Oecologia 161:221-226 